$\begin{array}{rr}\text { JURNAL } & \text { Volume } 11, \text { Nomor 5, Oktober } 2015 \\ \text { FIT(1)PATOLOGI } & \text { Halaman } 150-158 \\ \text { I N D O NES I A } & \text { DOI: } 10.14692 / \text { jfi.11.5.150 } \\ \text { ISSN: } 0215-7950 & \end{array}$

\title{
Mikobiota pada Buah Cabai untuk Pengendalian Hayati Colletotrichum capsici
}

\author{
Mycobiota on Chilli Fruits for \\ Biological Control of Colletotrichum capsici
}

\author{
Okky Setyawati Dharmaputra ${ }^{1,2 *}$, Lisdar Idwan Sudirman', Melly Fitriani1 \\ ${ }^{1}$ Institut Pertanian Bogor, Bogor 16680 \\ ${ }^{2}$ SEAMEO BIOTROP, Bogor 16134
}

\begin{abstract}
ABSTRAK
Colletotrichum capsici merupakan cendawan penyebab antraknosa pada buah cabai. Penggunaan agens hayati merupakan salah satu cara penanganan penyakit pascapanen pada produk hortikultura. Penelitian ini bertujuan menentukan potensi antagonis mikobiota pada buah cabai terhadap C. capsici. Cendawan patogen dan mikobiota calon antagonis diisolasi dari buah cabai merah besar yang diperoleh dari 3 pasar tradisional di Bogor. Isolasi $C$. capsici menggunakan metode penanaman pada medium agaragar dekstrosa kentang (ADK) yang mengandung kloramfenikol $\left(100 \mathrm{mg} \mathrm{L}^{-1}\right)$. Isolasi mikobiota calon antagonis dilakukan menggunakan metode pengenceran berseri yang dilanjutkan dengan metode cawan tuang pada medium ADK yang mengandung kloramfenikol $\left(100 \mathrm{mg} \mathrm{mL}^{-1}\right)$. Uji antagonisme dilakukan menggunakan metode biakan ganda pada medium ADK. Dari 4 isolat $C$. capsici yang diperoleh, isolat BIO 51046 memiliki patogenisitas tertinggi ketika diinokulasikan pada buah cabai merah besar var. IPB Perbani. Isolat mikobiota calon antagonis yang diperoleh ialah sebanyak 14 isolat yang terdiri atas 7 isolat cendawan berfilamen dan 7 isolat khamir. Tiga isolat cendawan berfilamen (Plectosphaerella cucumerina, isolat MF2, dan Aspergillus flavus) serta isolat khamir (Issatchenkia orientalis) memiliki kemampuan menghambat pertumbuhan C. capsici BIO 51046 lebih dari 70\%. Interaksi antara cendawan uji dengan $C$. capsici pada medium ADK menghasilkan tipe interaksi inhibisi mutual dan inhibisi patogen. Zona hambatan terbentuk pada inhibisi mutual (isolat MF vs $C$. capsici), sedangkan cendawan uji tetap mengalami pertumbuhan (P. cucumerina, A. flavus, I. orientalis vs $C$. capsici) pada inhibisi patogen. Plectosphaerella cucumerina dan I. orientalis tidak menyebabkan penyakit pada buah cabai var. IPB Perbani sehingga berpotensi sebagai agens hayati untuk C. capsici BIO 51046 penyebab penyakit antraknosa pada cabai.
\end{abstract}

Kata kunci: agens hayati, antraknosa, Issatchenkia orientalis, Plectosphaerella cucumerina

\begin{abstract}
Colletotrichum capsici is a pathogenic fungus causing anthracnose on various tropical fruits, especially chilli. Biological control agents have been used as an alternative method to control postharvest diseases. This study aims to examine the antagonistic potential of mycobiota on red chilli fruit against $C$. capsici. The pathogen was obtained from diseased red chilli fruits collected from three traditional markets in Municipality of Bogor, isolated on potato dextrose agar (PDA) medium containing chloramphenicol (100 $\left.\mathrm{mg} \mathrm{L}^{-1}\right)$. Candidates of antagonistic mycobiota were isolated from healthy chilli fruits using serial diution method, followed by pour-plate method on PDA medium containing chloramphenicol $\left(100 \mathrm{mg} \mathrm{L}^{-1}\right)$.
\end{abstract}

\footnotetext{
*Alamat penulis korespondensi: Departemen Biologi, Fakultas Matematika dan Ilmu Pengetahuan Alam, Institut Pertanian Bogor, Jalan Agatis, Kampus Dramaga, Bogor 16680.

Tel: 0251-8622833, Faks: 0251-8622833, Surel: okky@biotrop.org
} 
C. capsici isolate BIO51046 showed highest pathogenicity on chilli fruit var. IPB Perbani compared to other isolates. Seven isolates of filamentous fungi and 7 yeast isolates were obtained from healthy chilli fruits. Test of antagonism using dual culture method obtained 3 filamentous fungal isolates (Plectosphaerella cucumerina, MF2 and Aspergillus flavus) and 1 yeast isolate (Issatchenkia orientalis) which inhibited the growth of $C$. capsici BIO 51046 more than $70 \%$. Plectosphaerella cucumerina and I. orientalis did not cause any diseases on chilli fruits var. IPB Perbani. Therefore, these 2 isolates were considered as potential antagonist against C. capsici BIO51046 as the causal agent of anthracnose of chilli.

Key words: anthracnose, biocontrol agent, Issatchenkia orientalis, Plectosphaerella cucumerina

\section{PENDAHULUAN}

Produksi cabai merah besar di Indonesia pada tahun 2013 ialah sebesar 1012879 ton dengan produksi cabai merah besar tertinggi berada di Jawa Barat sebesar 250914 ton (BPS 2014). Salah satu penyakit pada buah cabai ialah antraknosa yang disebabkan oleh Colletotrichum spp. Pembusukan akibat antraknosa pada buah cabai akan terjadi pada saat buah matang sehingga menyebabkan penurunan jumlah dan kualitas buah cabai.

Pengendalian penyakit pascapanen pada buah-buahan dan sayuran dapat dilakukan dengan 3 cara, yaitu pengendalian fisik, kimia, dan biologi. Pengendalian secara fisik dan kimia kemungkinan dapat menyebabkan penurunan mutu buah-buahan dan sayuran serta menimbulkan polusi lingkungan, berpengaruh terhadap kesehatan manusia, dan dapat menimbulkan resistensi patogen terhadap fungisida.

Beberapa cendawan antagonis dilaporkan dapat digunakan sebagai agens hayati terhadap antraknosa pada beberapa buahbuahan dan sayuran. Siregar et al. (2007) melaporkan bahwa bakteri Bacillus polymyxa dan cendawan Trichoderma harzianum dapat mengendalikan cendawan penyebab antraknosa pada tanaman cabai. T. harzianum dan Gliocladium roseum dapat digunakan sebagai agens hayati terhadap $C$. acutatum dan $C$. gloeosporioides penyebab antraknosa pada buah-buahan (Zivkovic et al. 2010). Tujuan penelitian ini ialah menguji potensi antagonis mikobiota pada buah cabai merah besar terhadap $C$. capsici.

\section{BAHAN DAN METODE}

\section{Sampel Buah Cabai}

Buah cabai merah besar yang terserang antraknosa dan yang sehat diperoleh dari pasar tradisional di Bogor. Cabai var. Imperial-308 diperoleh dari pasar Anyar, sedangkan cabai var. Hibrida F1 Maraton diperoleh dari pasar Bogor dan pasar Gembrong. Cabai var. IPB Perbani yang sehat diperoleh dari kebun Leuwikopo, Institut Pertanian Bogor.

\section{Isolasi dan Identifikasi Cendawan Penyebab Antraknosa}

Buah cabai yang terinfeksi antraknosa diseka permukaannya menggunakan kertas tisu yang diberi etanol $70 \%$, selanjutnya buah dibilas dengan akuades steril dan dikeringanginkan. Jaringan kulit dan daging buah di antara bagian yang sakit dan sehat dipotong $(5 \mathrm{~mm} \times 5 \mathrm{~mm})$. Sebanyak 9 potongan jaringan kulit dan daging buah diletakkan pada medium agar-agar dekstrosa kentang (ADK) yang mengandung kloramfenikol $\left(100 \mathrm{mg} \mathrm{L}^{-1}\right)$ di dalam cawan petri (3 potong per cawan petri), selanjutnya diinkubasi pada suhu ruang $\left(28 \pm 2{ }^{\circ} \mathrm{C}\right)$ selama 5 hari. Setiap koloni cendawan yang diduga Colletotrichum spp. dimurnikan pada medium ADK tanpa kloramfenikol. Identifikasi Colletotrichum spp. menggunakan pustaka acuan Sutton (1980) dan Kumar et al. (2015). Biakan murni setiap isolat Colletotrichum dibuat preparat menggunakan pewarna laktofenol biru katun untuk mengamati ciri khusus menggunakan mikroskop dengan perbesaran 100-400×. Perbedaan antar spesies diamati 
berdasarkan pada bentuk konidium, ukuran (panjang dan lebar) konidium, dan keberadaan sklerotium. Persentase keberadaan cendawan Colletotrichum spp. ditentukan berdasarkan jumlah koloni setiap spesies Colletotrichum dari 9 potong kulit dan daging buah cabai pada medium ADK yang mengandung kloramfenikol (100 mg L $\left.{ }^{-1}\right)$.

\section{Uji Patogenisitas Isolat $C$. capsici}

Cabai var. IPB Perbani sehat dengan ukuran dan kematangan yang sama dibilas dengan air dan dikeringanginkan, selanjutnya permukaan buah disterilkan menggunakan etanol 70\%. Bagian pangkal dan tengah setiap buah digores vertikal dan horizontal, masing-masing $1 \mathrm{~cm}$ (Dharmaputra et al. 2007a). Di atas goresan tersebut ditempatkan inokulum isolat $C$. capsici yang berumur 7 hari (diameter $8 \mathrm{~mm}$ ). Sebagai kontrol di atas goresan ditempatkan potongan medium ADK murni (diameter $8 \mathrm{~mm}$ ). Setiap perlakuan dan kontrol diulang 7 kali. Selanjutnya cabai ditempatkan di dalam sebuah wadah plastik (diameter bagian bawah $14 \mathrm{~cm}$, diameter bagian atas $18 \mathrm{~cm}$, tinggi $15 \mathrm{~cm}$, volume $3 \mathrm{~L}$ ) yang telah didesinfeksi menggunakan etanol $70 \%$ dan dibuat dalam kondisi lembap (85\%). Kondisi kelembapan relatif $85 \%$ dibuat dengan meletakkan 5 buah kapas steril (2.5 g) yang telah diberi akuades steril (20 mL) di dalam setiap wadah, kemudian semua wadah diinkubasi pada suhu ruang $\left( \pm 28^{\circ} \mathrm{C}\right)$ selama 7 hari.

Pengamatan patogenisitas dilakukan terhadap luas permukaan cabai yang terinfeksi C. capsici dengan metode gravimetri, yaitu dengan cara menggambar tepi gejala pada selembar plastik transparan dan mencetak kembali pada karton tebal, kemudian bobot karton tersebut (g) dikonversi ke luas gejala $\left(\mathrm{mm}^{2}\right)$ berdasarkan bobot karton $0.6 \mathrm{mg}$ yang luasnya $100 \mathrm{~mm}^{2}$ (Rindita et al. 2015).

\section{Isolasi Cendawan Uji}

Isolasi cendawan selain $C$. capsici pada cabai sehat dilakukan menggunakan metode pengenceran berseri yang dilanjutkan dengan metode cawan tuang pada medium ADK yang mengandung kloramfenikol (100 mg L-1).
Sebanyak 100 g kulit dan daging buah cabai yang ditambahkan akuades steril hingga volumenya $500 \mathrm{~mL}$ ditempatkan di dalam blender, kemudian dihaluskan selama 1 menit sampai diperoleh suspensi cabai dengan pengenceran 1:5. Dari pengenceran ini dibuat pengenceran $1: 10 ; 1: 20 ; 1: 100$; dan 1:1000. Sebanyak $1 \mathrm{~mL}$ suspensi dari setiap pengenceran ditempatkan di dalam cawan petri (diameter $9 \mathrm{~cm}$ ), kemudian ditambahkan $12 \pm 1 \mathrm{~mL}$ medium ADK $\left(40 \pm 2{ }^{\circ} \mathrm{C}\right)$ yang mengandung kloramfenikol (100 mg L $\left.\mathrm{m}^{-1}\right)$ dan diinkubasi pada suhu ruang selama 7 hari.

Pengamatan dilakukan terhadap koloni cendawan yang berbeda warna dan pola pertumbuhannya, dan dipindahkan ke medium ADK tanpa kloramfenikol. Setiap isolat cendawan diuji sifat antagonisnya terhadap $C$. capsici yang patogenisitasnya terhadap cabai var. IPB Perbani paling tinggi.

\section{Uji Antagonisme antara Cendawan Uji dengan $C$. capsici secara in Vitro}

Setiap isolat cendawan selain $C$. capsici yang diisolasi dari kulit dan daging cabai sehat diuji sifat antagonisnya terhadap $C$. capsici yang patogenisitasnya paling tinggi menggunakan metode biakan ganda (Skidmore dan Dickinson 1976) (Gambar 1).

Colletotrichum capsici ditumbuhkan pada 3 waktu yang berbeda, yaitu pada waktu yang sama dengan inokulasi cendawan uji

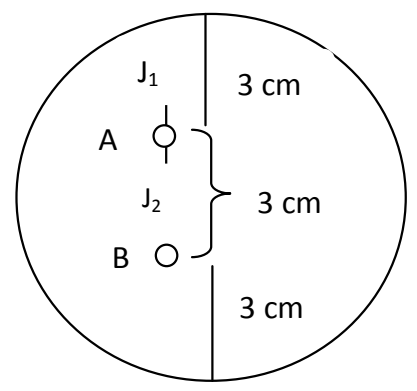

Gambar 1 Skema uji antagonisme antara cendawan uji dengan Colletotrichum capsici BIO 51046 pada medium ADK. A, C. capsici BIO 51046; B, cendawan uji; $\mathrm{J}_{1}$, jari-jari koloni C. capsici BIO 51046 yang tumbuh ke arah berlawanan dengan tempat cendawan uji; $\mathrm{J}_{2}$, jari-jari koloni C. capsici BIO 51046 yang tumbuh ke arah cendawan uji (mm). 
(cendawan berfilamen dan khamir), 3 hari setelah inokulasi cendawan uji (cendawan berfilamen), dan 7 hari setelah inokulasi cendawan uji (kelompok khamir). Setiap perlakuan diulang 3 kali. Semua cawan petri setelah inokulasi cendawan uji, masingmasing untuk kelompok cendawan berfilamen dan khamir diinkubasikan pada suhu ruang selama 7 hari. Persentase penghambatan terhadap pertumbuhan isolat $C$. capsici yang patogenisitasnya paling tinggi oleh cendawan uji dihitung berdasarkan rumus berikut (Fokkema 1978):

$\begin{aligned} & \text { Penghambatan } \\ & \text { pertumbuhan }(\%)\end{aligned}=\frac{\mathrm{J}_{1}-\mathrm{J}_{2}}{\mathrm{~J}_{1}} \times 100 \%$, dengan

$\mathrm{J}_{1}$, jari-jari koloni $C$. capsici yang tumbuh ke arah berlawanan dengan tempat cendawan uji; $\mathrm{J}_{2}$, jari-jari koloni $C$. capsici yang tumbuh ke arah tempat cendawan uji.

Cendawan uji yang menyebabkan persentase hambatan pertumbuhan $C$. capsici lebih dari $70 \%$ dianggap berpotensi sebagai antagonis. Pengamatan mekanisme antagonisme dilakukan secara makroskopi, yaitu dengan mengamati tipe interaksi antarcendawan (Wheeler dan Hocking 1993 yang dimodifikasi dari Magan dan Lacey 1984).

\section{Uji Patogenisitas Calon Agens Hayati}

Uji patogenisitas isolat cendawan antagonis yang menyebabkan persentase hambatan pertumbuhan $C$. capsici lebih dari $70 \%$ dilakukan dengan metode yang sama seperti pada uji patogenisitas isolat $C$. capsici pada cabai var. IPB Perbani. Setiap perlakuan diulang 6 kali.

\section{Rancangan Percobaan}

Semua uji-uji patogenisitas isolat $C$. capsici BIO 51046 pada cabai var. IPB Perbani, uji antagonisme antara cendawan uji dengan $C$. capsici BIO 51046 yang ditumbuhkan secara berpasangan pada 3 waktu yang berbeda, dan uji patogenisitas isolat cendawan antagonis terhadap cabai merah besar var. IPB Perbani disusun dalam rancangan acak lengkap.
Identifikasi Cendawan Antagonis yang Berpotensi sebagai Agens Hayati

Isolat cendawan antagonis yang berpotensi sebagai agens hayati dan tidak patogenik pada cabai diidentifikasi secara morfologi menggunakan pustaka Rodrigues et al. (2007) dan Varga dan Samson (2008). Biakan murni setiap cendawan antagonis dibuat preparat menggunakan pewarna laktofenol biru katun untuk mengamati ciri khusus dengan bantuan mikroskop. Identifikasi secara molekuler dilakukan dengan membandingkan sikuen DNA daerah D1/D2 dari subunit RNA ribosom (26S rRNA) (Hamby et al. 2012).

\section{HASIL}

\section{Cendawan dari Cabai yang Terserang Antraknosa}

Colletotrichum yang diisolasi dari cabai yang terserang antraknosa ialah $C$. capsici, $C$. gloeosporioides dan C. acutatum. Keberadaan C. capsici pada cabai yang diperoleh dari 3 pasar tradisional di Kotamadya Bogor lebih dominan (63.9\%) dibandingkan dengan $C$. gloeosporioides $(35.6 \%)$ dan C. acutatum $(13.3 \%)$.

\section{Patogenisitas $C$. capsici}

Sebanyak 4 isolat $C$. capsici telah diisolasi dari buah cabai yang terserang antraknosa dari pasar Anyar, pasar Bogor, dan pasar Gembrong. C. capsici BIO 51047 dan BIO 51048 diperoleh dari pasar Anyar, BIO 51049 diperoleh dari pasar Gembrong, dan BIO 51046 diperoleh dari pasar Bogor.

Luas permukaan gejala antraknosa pada cabai var. IPB Perbani akibat serangan $C$. capsici BIO 51046 ialah $294 \mathrm{~mm}^{2}$ (Tabel 1). Patogenisitas C. capsici BIO 51046 merupakan yang paling tinggi sehingga isolat ini digunakan untuk uji antagonisme.

Mikobiota selain $C$. capsici pada Buah Cabai dan Hasil Uji Antagonismenya dengan $C$. capsici

Pada pengujian ini, persentase penghambatan terhadap C. capsici BIO51046 
yang melebihi $70 \%$ ditunjukkan oleh 3 isolat cendawan berfilamen, yaitu Plectosphaerella cucumerina, isolat MF2, dan Aspergillus flavus serta satu isolat khamir Issatchenkia orientalis, yaitu berturut-turut 72.5, 76.7, 71.7 dan 77.3\% (Tabel 2).

Interaksi antara cendawan uji dengan C. capsici pada medium ADK menghasilkan 2 tipe interaksi (Gambar 2), yaitu inhibisi mutual (tipe B) yang ditunjukkan terbentuknya zona hambatan kurang dari $2 \mathrm{~mm}$ dan inhibisi

Tabel 1 Hasil uji patogenisitas 4 isolat Colletotrichum capsici terhadap buah cabai merah besar

\begin{tabular}{lc}
\hline $\begin{array}{l}\text { Kode isolat } \\
\text { C. capsici }\end{array}$ & $\begin{array}{l}\text { Luas } \\
\text { antraknosa }\end{array}$ \\
\hline BIO 51046 & $\begin{array}{c}\text { permukaan buah } \\
\left(\mathrm{mm}^{2}\right)\end{array}$ \\
BIO 51048 & $294.0 \mathrm{a}$ \\
BIO 51049 & $156.8 \mathrm{ab}$ \\
BIO 51047 & $147.8 \mathrm{ab}$ \\
$15.5 \mathrm{~b}$ \\
\hline
\end{tabular}

Angka-angka yang diikuti oleh huruf yang sama tidak berbeda nyata berdasarkan uji banding Duncan pada taraf kepercayaan 99\%. patogen (tipe E) yang ditunjukkan dengan dihambatnya cendawan patogen, sedangkan cendawan uji tetap mengalami pertumbuhan. Hasil interaksi antara P. cucumerina dan $A$. flavus (cendawan berfilamen) dan I. orientalis (khamir) dengan C. capsici BIO 51046 menunjukkan tipe E, sedangkan interaksi antara isolat MF 2 (cendawan berfilamen) dengan C. capsici BIO 51046 menunjukkan tipe B.

\section{Kemampuan Cendawan Antagonis dalam Menyebabkan Penyakit pada Buah Cabai}

Isolat MF 2 dan $A$. flavus menyebabkan penyakit pada buah cabai merah besar var. IPB Perbani, sedangkan isolat $I$. orientalis (Gambar 3) dan P. cucumerina (Gambar 4) tidak menyebabkan gejala penyakit. Kemampuan isolat cendawan antagonis dalam menyebabkan penyakit dan luas permukaan gejala penyakit dapat dilihat pada Tabel 3 .

\section{PEMBAHASAN}

Mikroorganisme antagonis dapat digunakan sebagai agens hayati dalam menekan

Tabel 2 Persentase hambatan pertumbuhan Colletotrichum capsici BIO 51046 oleh isolat cendawan uji, jarak zona hambatan, dan tipe interaksi setelah 7 hari inkubasi pada suhu ruang $\left(28 \pm 2{ }^{\circ} \mathrm{C}\right)$

\begin{tabular}{|c|c|c|c|c|c|c|c|c|c|c|}
\hline \multirow[t]{2}{*}{$\begin{array}{l}\text { Isolat cendawan } \\
\text { uji }\end{array}$} & \multirow[t]{2}{*}{ Asal cabai } & \multicolumn{3}{|c|}{$\begin{array}{c}\text { Hambatan pertumbuhan } \\
(\%)\end{array}$} & \multicolumn{3}{|c|}{$\begin{array}{l}\text { Jarak zona hambatan } \\
(\mathrm{mm})\end{array}$} & \multicolumn{3}{|c|}{ Tipe interaks } \\
\hline & & $\mathrm{a}$ & $\mathrm{b}$ & $\mathrm{c}$ & $\mathrm{a}$ & $\mathrm{b}$ & $\mathrm{c}$ & $\mathrm{a}$ & $\mathrm{b}$ & $\mathrm{c}$ \\
\hline $\begin{array}{l}\text { Plectosphaerella } \\
\text { cucumerina }\end{array}$ & Pasar Gembrong & $32.00 \mathrm{abc}$ & $72.5 \mathrm{ab}$ & - & 0 & 0 & - & $E$ & $\mathrm{E}$ & \\
\hline MF 2 & Pasar Gembrong & $47.3 \mathrm{a}$ & $76.7 \mathrm{a}$ & - & 1 & 0 & - & B & B & - \\
\hline MF 3 & Pasar Gembrong & $38.5 \mathrm{ab}$ & $59.3 \mathrm{bcd}$ & - & 0 & 0 & - & $\mathrm{E}$ & $\mathrm{E}$ & - \\
\hline MF 6 & Pasar Gembrong & $37.7 \mathrm{ab}$ & $66.7 \mathrm{abc}$ & - & 0 & 0 & - & $\mathrm{E}$ & B & - \\
\hline $\begin{array}{l}\text { Aspergillus } \\
\text { flavus }\end{array}$ & Pasar Bogor & $46.7 \mathrm{a}$ & $71.7 \mathrm{ab}$ & - & 0 & 0 & - & $\mathrm{E}$ & $\mathrm{E}$ & - \\
\hline MF 10 & Pasar Bogor & $37.7 \mathrm{ab}$ & $53.7 \mathrm{~cd}$ & - & 0 & 0 & - & B & $\mathrm{E}$ & - \\
\hline MF 14 & Pasar Bogor & $27.7 \mathrm{bcd}$ & $48.3 \mathrm{~d}$ & - & 0 & 0 & - & B & $\mathrm{E}$ & - \\
\hline MF 4 & Pasar Gembrong & $37.7 \mathrm{ab}$ & - & $63.0 \mathrm{ab}$ & 0 & - & 0 & $\mathrm{E}$ & - & $\mathrm{E}$ \\
\hline MF 7 & Pasar Gembrong & $43.5 \mathrm{a}$ & - & $62.0 \mathrm{ab}$ & 0 & - & 0 & B & - & E \\
\hline MF 8 & Pasar Gembrong & $14.0 \mathrm{~d}$ & - & $38.0 \mathrm{c}$ & 0 & - & 0 & B & - & B \\
\hline $\begin{array}{l}\text { Issatchenkia } \\
\text { orientalis }\end{array}$ & Pasar Bogor & $45.3 \mathrm{a}$ & - & $77.3 \mathrm{a}$ & 0 & - & 0 & $\mathrm{E}$ & - & $\mathrm{E}$ \\
\hline MF 12 & Pasar Anyar & $20.0 \mathrm{~cd}$ & - & $38.5 \mathrm{c}$ & 0 & - & 0 & B & - & $\mathrm{E}$ \\
\hline MF 13 & Pasar Bogor & $28.0 \mathrm{bcd}$ & - & $64.7 \mathrm{ab}$ & 0 & - & 0 & $\mathrm{E}$ & - & $\mathrm{E}$ \\
\hline MF 15 & Pasar Anyar & $43.0 \mathrm{ab}$ & - & $57.3 \mathrm{~b}$ & 0 & - & 0 & $\mathrm{E}$ & - & B \\
\hline
\end{tabular}

Angka-angka yang diikuti oleh huruf yang sama sama pada kolom yang sama tidak berbeda nyata berdasarkan uji Duncan pada taraf kepercayaan 99\%; a, C. capsici BIO 51046 ditumbuhkan pada waktu yang sama dengan cendawan uji (cendawan berfilamen dan khamir); b, C. capsici BIO 51046 ditumbuhkan 3 hari setelah inokulasi cendawan uji (cendawan berfilamen); c, C. capsici BIO 51046 ditumbuhkan. 


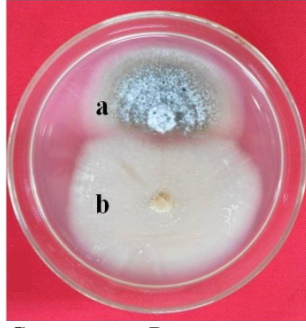

C. capsici vs $P$. cucumerina

1

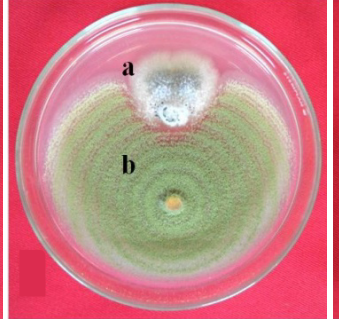

C. capsici vs A. flavus

2

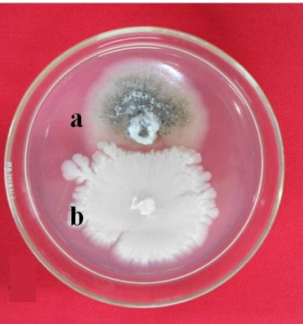

C. capsici vs I. orientalis

3

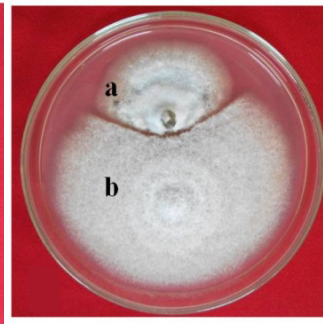

C. capsici vs MF 2

4

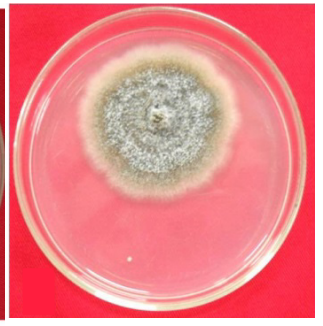

Kontrol (C. capsici) 5

Gambar 2 Uji antagonisme antara Colletotrichum capsici BIO 51046 dengan cendawan uji pada medium agar-agar dekstrosa kentang setelah 7 hari inkubasi pada suhu ruang $\left(28 \pm 2{ }^{\circ} \mathrm{C}\right)$. 1, Plectosphaerella cucumerina (tipe interaksi E); 2, Aspergillus flavus (tipe interaksi E); 3, Issatchenkia orientalis (tipe interaksi E); 4, isolat MF 2 (tipe interaksi B); dan 5, kontrol. a, C. capsici BIO 51046; b, cendawan uji.

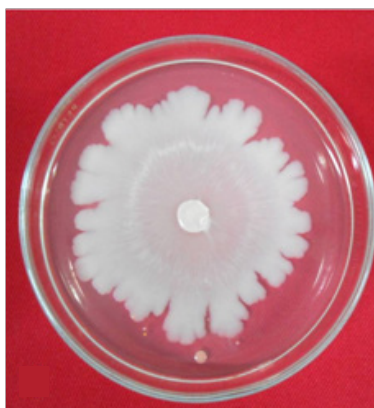

a

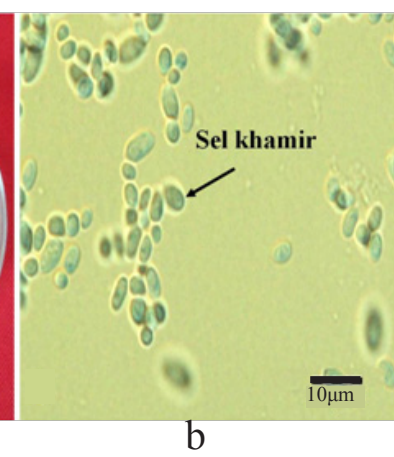

Gambar 3 Issatchenkia orientalis. a, Koloni biakan murni pada medium agar-agar dekstrosa kentang setelah inkubasi 7 hari pada suhu ruang $\left(28 \pm 2{ }^{\circ} \mathrm{C}\right)$; $\mathrm{b}$, Mikrograf sel khamir.

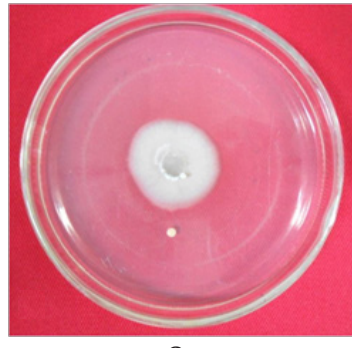

a

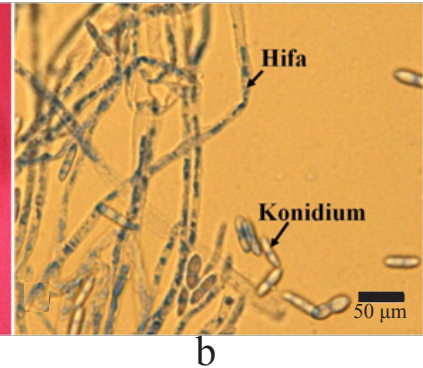

Gambar 4 Plectosphaerella cucumerina. a, Koloni biakan murni pada medium agaragar dekstrosa kentang setelah inkubasi 7 hari pada suhu ruang $\left(28 \pm 2{ }^{\circ} \mathrm{C}\right)$; b, Mikrograf morfologi hifa dan konidium.

pertumbuhan patogen dengan syarat memiliki kemampuan beradaptasi terhadap kondisi lingkungan yang nutrisinya rendah, tidak menyebabkan penyakit pada inang, tidak menghasilkan metabolit berbahaya, dan efektif melawan patogen dengan kisaran inang luas.
Terdapat 2 pendekatan penggunaan mikroorganisme antagonis sebagai agens hayati penyakit pascapanen pada buah, yaitu menggunakan mikroorganisme antagonis yang berasal dari buah itu sendiri dan dapat menggunakan mikroorganisme dari buah lain untuk mengendalikan patogen (Sharma et al. 2009). Fusamen sp. dan Oidiodendron sp. yang diisolasi dari buah tomat var. Arthaloka dapat digunakan sebagai agens hayati Alternaria solani BIO 1134 yang diisolasi dari buah tomat varietas yang sama (Dharmaputra et al. 2007a). Khamir Cryptococcus laurentii yang diisolasi dari permukaan buah pir dapat mengendalikan busuk buah persik disebabkan oleh Botrytis cinerea (Zhang et al. 2007). Endomyces decipiens BIO 21135 dikombinasikan dengan sodium bikarbonat $0.8 \%$ dapat mereduksi serangan hawar awal buah tomat var. Arthaloka (Dharmaputra et al. 2007b). Dua spesies khamir, yaitu Pichia anomala dan Candida intermedia berpotensi untuk pengendalian antraknosa pada buah advokat (Fitriati et al. 2013).

Selain berasal dari buah, mikroorganisme antagonis dapat diisolasi dari permukaan daun, bunga dan sayuran (Beasley et al. 2001; Abano dan Sam-Amoah 2012). Khamir yang diisolasi dari rizosfer, daun dan tangkai tanaman tebu dan jagung dapat mengendalikan C. sublineolum dan C. graminicola penyebab antraknosa pada sorgum dan jagung (RosaMagri et al. 2011). Selain mikobiota, antagonis dapat berupa bakteri (Sharma et al. 2009). 
Tabel 3 Uji patogenisitas isolat mikobiota antagonis pada buah cabai merah besar dan kontrol Colletotrichum capsici BIO 51046

\begin{tabular}{lcc}
\hline Isolat uji & $\begin{array}{c}\text { Patogenisitas pada buah cabai } \\
\text { MF 2 }\end{array}$ & $\begin{array}{c}\text { Luas permukaan gejala penyakit } \\
\left(\mathrm{mm}^{2}\right)\end{array}$ \\
Aspergillus flavus & + & 308.34 \\
Plectosphaerella cucumerina & + & 461.12 \\
Issatchenkia orientalis & - & - \\
C. capsici BIO 51046 & - & - \\
$\mathrm{K}_{1}$ & + & 294.00 \\
$\mathrm{~K}_{2}$ & - & - \\
\hline +, menyebabkan penyakit pada buah cabai; - , tidak menyebabkan penyakit pada buah cabai; $\mathrm{K}_{1}$, kontrol 1 (medium \\
agar-agar dekstrosa kentang tanpa C. capsici BIO 51046); $\mathrm{K}_{2}$, kontrol 2 (tanpa medium agar-agar dekstrosa kentang \\
dan tanpa C. capsici BIO 51046).
\end{tabular}

Pada uji antagonisme antara cendawan uji dengan $C$. capsici BIO 51046, cendawan patogen ditumbuhkan pada 3 waktu yang berbeda. Hal tersebut dikarenakan setiap isolat, baik cendawan uji dan cendawan patogen, memiliki kecepatan pertumbuhan berbeda. Persentase hambatan pertumbuhan C. capsici BIO 51046 yang ditumbuhkan 3 dan 7 hari setelah inokulasi cendawan uji (cendawan berfilamen) lebih tinggi dibandingkan dengan yang ditumbuhkan bersama cendawan uji. Pengamatan secara visual pada koloni khamir dan C. capsici BIO 51046 terjadi saling kontak tanpa membentuk zona hambatan.

Wilson dan Wisniewski (1989) melaporkan bahwakhamir dapatmenghasilkan polisakarida ekstraselulase untuk meningkatkan daya tahan dan pelekatannya pada buah-buahan dan sayuran, dapat menggunakan nutrisi yang tersedia dengan cepat, tidak terpengaruh oleh perlakuan pestisida, mampu menghambat perkecambahan spora dan pertumbuhan cendawan patogen. Selain itu, khamir memiliki potensi yang cukup besar sebagai agens hayati dalam mengendalikan serangan penyakit pascapanen pada buah-buahan, karena mampu mengolonisasi permukaan buah pada kondisi lapangan dan dapat beradaptasi pada kondisi penyimpanan pada suhu dan konsentrasi oksigen rendah serta konsentrasi karbondioksida tinggi (Tian et al. 2004).

Atkins et al. (2003) melaporkan bahwa $P$. cucumerina berpotensi sebagai agens hayati terhadap nematoda. Walaupun demikian, perlu penelitian lebih lanjut tentang kemungkinan pengendalian antraknosa menggunakan $P$. cucumerina. Menurut Bleve et al. (2006), I. orientalis galur $16 \mathrm{C} 2$ dan $2 \mathrm{C} 2$ yang diisolasi dari buah anggur dapat mereduksi serangan Aspergillus carbonarius dan A. niger pada buah anggur. Kedua spesies cendawan tersebut dapat menghasilkan okratoksin pada buah anggur. Chanchaichaovivat (2007) melaporkan bahwa I. orientalis galur ER1 dapat mereduksi serangan antraknosa pada cabai sebesar $76.6 \%$.

Empat isolat cendawan uji yang diisolasi dari cabai merah yang sehat menunjukkan daya hambat terhadap pertumbuhan $C$. capsici BIO 51046 lebih dari $70 \%$ pada uji in vitro dalam medium tumbuh buatan. Keempat isolat cendawan tersebut ialah $P$. cucumerina, isolat MF2, dan A. flavus, dan I. orientalis. Issatchenkia orientalis dan P.cucumerina tidak menyebabkan penyakit pada buah cabai var. IPB Perbani sehingga keduanya berpotensi sebagai agens pengendalian hayati. Walaupun demikian, penelitian lanjut diperlukan untuk memperoleh informasi tentang potensi $I$. orientalis dan $P$. cucumerina sebagai agens hayati C. capsici pada kondisi lapangan (in vivo).

\section{UCAPAN TERIMA KASIH}

Ucapan terima kasih penulis sampaikan kepada Direktur SEAMEO BIOTROP atas izin penggunaan sarana dan fasilitas laboratorium 
Fitopatologi, kepada Ina Retnowati yang telah membantu dan memberikan saran, Edi Suryadi dan Nijma Nurfadila yang membantu selama penelitian. Ucapan terima kasih juga disampaikan kepada BIDIK MISI yang membantu sebagian dana penelitian serta Atit Kanthi yang mengidentifikasi isolat cendawan dan khamir secara molekuler.

\section{DAFTAR PUSTAKA}

Atkins SD, Clark IM, Sosnowska D, Hirsch PR, Kerry BR. 2003. Detection and quantification of Plectosphaerella cucumerina, a potential biological control agens of potato cyst nematodes, by using conventional PCR, real time PCR, selective media, and baiting. App Environ Microbiol. 69(8):4788-4793. DOI: http://dx.doi. org/10.1128/AEM.69.8.4788-4793.2003.

[BPS] Badan Pusat Statistik. 2014. Produksi Cabe Besar Menurut Provinsi. http:// www.pertanian.go.id/EIS-ASEM HORTI-2014/Prod-Cb.Besar-ASEMHORTI.pdf [diakses 19 Juni 2015].

Beasley DR, Joyce DC, Coates LM, Wearing AH. 2001. Saprophytic microorganisms with potential for biological control of Botrytis cinerea on Geraldton waxflower. Aust J Experimental Agr. 4(15):697-703. DOI: http://dx.doi.org/10.1071/EA00112.

Bleve G, Grieco F, Cozzi G, Logrieco A, Visconti A. 2006. Isolation of epiphytic yeast with potential for biocontrol of Aspergillus carbonarius and A. niger on grape. J Food Microbiol. 108:204209. DOI: http://dx.doi.org/10.1016/j. ijfoodmicro.2005.12.004.

ChanchaichaovivatA, Ruenwongsa P, Panijpan B. 2007. Screening and identification of yeast strains fruits and vegetables: potential for biological control of postharvest chilli anthracnose (Colletotrichum capsici). Biol Control. 42:326-335. DOI: http://dx.doi. org/10.1016/j.biocontrol.2007.05.016.

Dharmaputra OS, Retnowati I, Haryani FS. 2007a. Mycobiota of tomato fruits: their effects on Alternaria solani causing early blight. Di dalam: Proceedings of the $1^{\text {st }}$
International Conference of Crop Security; 2005 Sept 20-22; Malang (ID): PFI Komda Malang dan Jurusan HPT, Universitas Brawijaya. Hlm 284-290.

Dharmaputra OS, Retnowati I, Paramita JY. 2007b. Use of sodium bicarbonate and Endomyces decipiens to control Alternaria solani causing early blight of tomato. Di dalam:Proceedings of the $3 \mathrm{rd}$ Asian Conference on Plant Pathology; 2007 Agust 20-24; Yogyakarta (ID): PFI dan Jurusan HPT, Fakultas Pertanian, Universitas Gadjah Mada. Hlm 309-310.

Abano EE, Sam-Amoah LK. 2012. Application of antagonistic microorganisms for the control of postharvest decay in fruits and vegetables. IJABR. 2(1):1-8.

Fitriati Y, Wiyono S, Sumarauw IO. 2013. Khamir antagonis untuk pengendalian penyakit antraknosa pada buah avokad selama penyimpanan. J Fitopatol Indones. 9(5):153-159. DOI: http://dx.doi. org/10.14692/jfi.9.5.153.

Fokkema NJ. 1978. Fungal antagonism in the phylosphere. Ann Appl Biol. 89:115-117. DOI: http://dx.doi. org/10.1111/j.1744-7348.1978.tb02582.x.

Hamby KA, Hernandez A, Boundy-Mills K, Zalom FG. 2012. Associations of yeast with spotted wing Drosophila (Drosophila suzukii; Diptera: Drosophilidae) in cherries and rasberries. App Environ Microbiol. 78(14):4869-4873. DOI: http://dx.doi. org/10.1128/AEM.00841-12.

Kumar S, Singh V, Garg R. 2015. Cultural and morphological variability in Colletotrichum capsici causing anthracnose disease. Int $\mathrm{J}$ Curr Microbiol App Sci. 4(2):243-250.

Magan N, Lacey J. 1984. The effect of water activity, temperature and structure on interactions between field and storage fungi. Trans Brit Mycol Soc. 92:83-93. DOI: $\quad$ http://dx.doi.org/10.1016/S00071536(84)80214-4.

Rindita, Sudirman LI, Koesmaryono Y. 2015. Air quality bioindicator using the population of epiphytic macrolichens in Bogor City, West Java. Hayati J Biosci. 22(2):53-59. 
Rodrigues P, Soares C, Kozakiewics Z, Paterson RRM, Lima N, Venancio A. 2007. Identification and characterization of Aspergillus flavus and aflatoxins. Di dalam: Mendez-Vilas A, editor. Communicating Current Research andEducational Topics and Trends in Applied Microbiology. Lisbon (PT). Hlm 527-534.

Rosa-Magri MM, Tauk-Tornisielo SM, Ceccato-Antonini SR. 2011. Bioprospection of yeasts as biocontrol agents against phytopathogenic molds. Braz Arch Biol Technol. 54(1):1-5. DOI: http://dx.doi.org/10.1590/S151689132011000100001.

Sharma RR, SinghD, Singh R. 2009. Biological control of postharvest diseases of fruits and vegetables by microbial antagonists: A review. J Biocontrol. 50:205-221. DOI: $\quad$ http://dx.doi.org/10.1016/j. biocontrol.2009.05.001.

Siregar AN, Ilyas S, Fardiaz D, Murniati E, Wiyono S. 2007. Penggunaan agens biokontrol Bacillus polymyxa dan Trichoderma harzianum untuk peningkatan mutu benih cabai dan pengendalian penyakit antraknosa. J Peny Pert. 2(2):105-114.

Skidmore AM, Dickinson CH. 1976. Colony interactions and hyphal interference between Septoria nodorum and phylloplane fungi. Trans Brit Mycol Soc. 66(1):57-64. DOI: http://dx.doi.org/10.1016/S00071536(76)80092-7.

Sutton BC. 1980. The Coelomycetes; Fungi Imperfecti with Pycnidia, Acervuli and Stromata. Kew (GB): Commonwealth Mycological Institute.
Tian SP, Qin GZ, Xu Y, Wang YS. 2004. Application of antagonistic yeasts under field conditions and their biocontrol ability against postharvest diseases of sweet cherry. Acta Bot Sinica. 46(11):13241330.

Varga J, Samson RA. 2008. Aspergillus in the genomic era. Ed ke-1. Wageningen (NL): Wageningen Academic Pub. DOI: http:// dx.doi.org/10.3920/978-90-8686-635-9.

Wheeler KA, Hocking AD. 1993. Interactions among xerophilic fungi associated with dried salted fish. J Applied Bacteriol. 74:164-169. DOI: http://dx.doi. org/10.1111/j.1365-2672.1993.tb03010.x.

Wilson CL, Wisniewski ME. 1989. Biological control of postharvest diseases of fruits and vegetables: an emerging technology. Ann Rev Phytopathol. 27:425-441. DOI: http://dx.doi.org/10.1146/annurev. py.27.090189.002233.

Zhang H, Zheng X, Yu T. 2007. Biological control of postharvest diseases of peach with Cryptococcus laurentii. Food Control 18:287-291. DOI: http://dx.doi. org/10.1016/j.foodcont.2005.10.007.

Zivkovic S, Stojanovic S, Ivanovic Z, Gavrilovic V. 2010. Screening of antagonistic activity of microorganisms against Colletotrichum acutatum and Colletotrichum gloeosporioides. Arch Biol Sci. 62(3):611-623. DOI:http://dx.doi. org/10.2298/ABS1003611Z. 